\title{
Interactive language learning activities for learners' communicative ability
}

\author{
Siti Fatimah Omar' ${ }^{1}$, Haslinda Sutan Ahmad Nawi², Tengku Shahrom Tengku Shahdan ${ }^{3}$, \\ Rita Wong Mee Mee ${ }^{4}$, Lim Seong Pek ${ }^{5}$, Fatin Syamilah Che Yob $^{6}$ \\ ${ }^{1,2}$ Faculty of Communication, Visual Art and Computing, Universiti Selangor, Malaysia \\ ${ }^{3,4,5,6}$ Faculty of Education and Social Sciences, Universiti Selangor, Malaysia
}

\section{Article Info}

Article history:

Received Mar 24, 2020

Revised Sep 11, 2020

Accepted Oct 10, 2020

\section{Keywords:}

Communicative

Interactive activities

Interactive learning

Motivation

Self-confidence

\begin{abstract}
Learners' communicative in English language has been unsatisfactory due to the factors that affect their self-confidence and motivation to speak. However, the problem persisted even though ways were used to overcome the lack of communicative ability among learners in Malaysia. Therefore, this study was conducted to address learners' perceptions of interactive language learning activities in improving English-speaking ability. The study aimed to analyse the effectiveness of the interactive language learning activities in motivating learners to speak in language classroom. A set of questionnaires containing two sections with 30 questions was administered. There were 50 primary school learners selected randomly to participate in this study. The results were collected and presented in the form of tables. The finding showed that self-confidence, motivation and learning environment affect the learners' English language speaking ability and the results indicated that interactive language learning activities are able to overcome problems pertaining to communicative in language classroom. In conclusion, interactive language learning activities improved the learners' English language speaking ability.
\end{abstract}

This is an open access article under the CC BY-SA license.

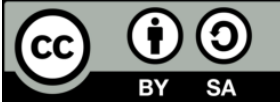

\section{Corresponding Author:}

Siti Fatimah Omar,

Faculty of Communication, Visual Art and Computing,

Universiti Selangor,

Bestari Jaya Campus, Selangor Darul Ehsan, Malaysia.

Email: ctpatimah@unisel.edu.my

\section{INTRODUCTION}

The use of learning methods plays an important role and receives special attentions for a learner's life. We live in digital era, where everyone wants something efficient, effective, dynamic, fast and interactive [1]. The term 'interactive' appears in two distinct strands of educational research discourse: one concerning pedagogy and the other concerning new technologies in education. Teaching learners with traditional method where there is only one way of communication is no longer effective. The word 'interactive' is the key to have an effective [2] and efficient teaching and learning process where the teacher can grab learners' attention and learners can learn more in comparison to that of the traditional method. Traditionally, most of the learners have been acquiring information and knowledge through less involvement of learners whereby learners only sit and listen to the unfaltering lectures. In addition, learners will copy down the endless indescribable notes that have been written on the whiteboard. Based on a research result conducted by Atiyah, El Sherbing and Guirguis [3], results showed that the teacher is the most dominant person in a classroom and the teacher is responsible for all learners. Furthermore, learners only acquire the 
knowledge but do not know how to apply it in real-life situations as they are not indulged in inquiry-based education and problem solving. Thus, learners have less opportunity to contribute in the lesson which is leading to unsupportive classroom environment and passive learners.

Moreover, in Malaysia, English language acts as second language learnt in school after Malay language. Many of these learners faced difficulty communicating in the target language and eventually gave up speaking in English language. Learners tend to shy away from using the target language when they find it hard to relay their points in English and they continue to express their ideas by using native language [4]. Consequently, it affects their level of confidence to communicate in English language. If situation to the like of the above persisted, learners' self-confidence will deteriorate, and many will shy away from communicating in English language [5]. In addition, the limitation of learners' vocabulary is one of the many factors that affect the learners' confidence level [6]. When learning and teaching take place, wide vocabularies are used in order to deliver the knowledge. Both teachers and learners need to have similarities in words so that they the same understanding of a conversation. Learners hesitated to involve themselves in the learning and teaching process as they are not confident to share their ideas due to the lack of vocabulary [7]. Due to this, lessons will be affected and limited exchange of productive communication to take place between learners and teachers.

In overcoming the unsupportive classroom environment and passive learners, Interactive Language Learning Activities (ILLA) is implemented in current language teaching as it helps to improve learners' English-speaking ability. Speaking skills need to be enhanced with language activities through interactive learning as interactive learning activities provide opportunities for improvement are highly importance [8]. In addition, interactive language learning activities encourage learners to speak their thoughts and ideas in many ways. Learners have the chance to learn from their teachers and peers, enhance their language, process of acquiring knowledge as well as gather their thoughts and creating logical thoughts [9]. Therefore, teachers need to implement the best way to enhance the learners' English-speaking ability. Specifically, teachers need to fully use the interactive learning environment as it encourages learners' engagements and participation in the lesson that lead to active learners and effective learning. Putting in mind that interactive classrooms are not limited to technology-based teaching spaces alone.

\section{LITERATURE REVIEW}

Education today has changed over time. With the ever growing of Generation Z, born between 1995 and 2012, are more Internet savvy compared to their Generation Y counterparts. Thus, there has been a dire need for new teaching and learning model that suit this "Digital Natives" yet penury generation to explore. The most important skill in self-expression and gaining knowledge is learners' speaking ability [10]. To emphasize the importance of speaking among the learners, teachers implement a series of methods that help to engage the learners and encouraging them to speak better. As a human being, communication plays a vital role in our lives. We communicate to deliver messages, convey and changing information as well as reporting things that are happening in our lives. To communicate, it is not necessarily to speak but you can have it in easier by sending messages through the usage of technology. However, people need to master speaking skills in order to communicate effectively and speaking is highlighted as the major component in fulfilling the target in communication [7]. In addition, speaking is said to be significant language skill in education and personal life [10]. Speaking is defined as a process that involves the thoughts and expressing it verbally. It means, the thoughts will first appear in our brain then only we articulate what we think [9].

In Malaysia, it is seen that there are a number of learners from primary schools, secondary school and tertiary level who are not proficient in speaking regardless the language [11]. When the learners cannot grasp the basic skills of speaking at early age, it affects their performance in many ways. In relation to the statement stated, foreign language learners have to acquire the fundamental language skills due to its importance usage in communication [7]. The ability to use and speak a world-wide language gives them nothing but benefits as they can indirectly enhance their knowledge and skills as well as assist them in terms of job- wise; having said that, speaking skills need to be improved among the learners. As learners spend most of their times in school acquiring knowledge and enhance their skills, teachers and their effective teaching and learning method play a vital role. A vary learner-centred and interactive method of teaching need to be implemented in order to improve the learners' speaking skills [9]. Besides, he mentioned that speaking is a learner-centred activity due to the language production activities implementation and had, thus, proposed the enforcement of interactive teaching strategy in improving learners' speaking skills which the focus is on enhancing the second language. Compared to other language skills, speaking is emphasized as the important component in achieving the purpose of communication [8, 12-15]. With the implementation of interactive teaching method, teachers eventually will conduct interactive language learning activities to complement their method of teaching. 
Sufficient and positive environments of a classroom help the learners to learn better. Therefore, the ability to be proficient in a language particularly depends on the environment provided by the teachers, according to the learners' autonomy. Thus, interactive language activities assist the learners to improve their proficiency [8]. Supporting the statement, Marzuki, et al. [4] analysed that learners are hardly sharing their opinions and thought during the speaking activities. Consequently, the learners can improve their speaking skills once the interactive speaking strategy is executed. The teaching strategy can be varied but the ending product should be focusing on improving the learners' speaking skills. As for that, interactive language learning activities aid the learners in acquiring and use the language at their maximum level. In interactive classroom environment, it enables learners to move around without getting fix in a certain arrangement where they can maximize the classroom space. Moreover, learners are said to have the opportunity to communicate with their peers directly and taking account their feelings and emotions [16]. Owing to the interactive language learning activities, there are numerous activities that can be conducted in classroom such as creative drama, role-playing, problem-solving, discussion and group. These activities help the learners to share their emotions and thoughts which will be shifted to the learning environment as it allows the active learning and teaching.

Thereupon, a few studies have been conducted to prove some of the stated activities in improving learners' speaking skills. The interactive storytelling strategy affects the English foreign language learners' improvement in speaking skills as well as their classroom activities [4]. Moreover, listening to and telling the story do not end there. It continues with the learners work as storytellers. They need to express and tell the selected story by using their own words. Hence, learners are then able to polish and enhance their vocabularies as they need select the best words that fit the description of their story [4]. Meanwhile, storytelling motivates learners in speaking [17]. Furthermore, it improves the learners' competence speaking. It is because communication between teachers and learners naturally grow stronger [4]. Based on their research, their respondents are not only improving in terms of generating and exploring critical questions, but they are able to enhance their vocabularies as well as develop their ability in retelling the story and choosing the words wisely. Equally important, interactive storytelling helps to improve the classroom activities learners' speaking skills.

On the other hand, drama-based activities like improvisation, playwriting and rehearsals help to provide opportunities for autonomous use of spontaneous spoken language in an informal setting that encourages individuality [18]. It means that the activities can promote speaking if it is focusing on the learners by providing an environment where each of learners can experience it. Furthermore, these activities eventually can improve learners' fluency and clarity of speech even though there are grammatical errors plus sentence structures inaccuracy. The oral input is increased due to the fact that learners are involved in both experiential and activity oriented. Learners are keen to speak if they can relate the activities towards their background knowledge or experiences [18]. As a result, learners' have become more confident and strongwilled as well as brave to share their opinions and thoughts voluntarily. As a whole, learners' English speaking can be improved by using interactive language learning activities. However, teachers need to implement this method according to the learners' level of proficiency. In addition, teachers need to figure out the learners' weaknesses in order to execute the most suitable and effective activities for the lesson.

\section{RESEARCH METHOD}

This particular study aims to figure out the connection between the problems that affect the learners' English-speaking ability and Interactive Language Learning Activities (ILLA) that can be used as a method to overcome the problems in communicating in the target language. Therefore, this study uses quantitative method to analyse the effectiveness of the interactive language learning activities in motivating learners to speak in language classroom. Tis method shows a cause and effect relationship with numerical data and hard facts. The results can be shown in statistics, tables, graphs as well as charts. Quantitative method is a method that uses measurable variables and statistical procedures can be used to analyse the numbered data in instruments [19]. Hence, quantitative method fits this study the most as it aids the study with clear and understandable data.

\subsection{Sampling}

The researchers adopted random sampling in this study. Random sampling is where participants are chosen correspondingly [19] by choosing the samples from the whole population of the local primary schools in Malaysia. This shows that every learner undertaking primary school education has the possibility to participate in the study. Thus, the participants need to have the given criteria to ensure their participation in the study is valid. In this study, the main aims are to analyse the effectiveness of interactive language learning activities in improving learners' English speaking and to identify the learners' motivation level in 
speaking English language as the target language. There were 50 learners randomly selected as the participants in total of (male $=20$, female $=30$ ). The age of the participants, at the time of the study, was 10 years old and they were exposed to the local curriculum similar to all primary schools in Malaysia. In addition, the participants participated in the survey are voluntary.

\subsection{Research instruments}

In this study, questionnaire was used and was adapted from Itayem [20]. As for the questionnaire, Itayem [20] provides the most similar questionnaire on interactive language learning but focusing on different activity. Similarly, Likert Scale was used as a measurement to get the data. The Likert Scale of the questions is 1 to 5 which is 1 (Strongly Agree), 2 (Agree), 3 (Neural), 4 (Disagree) and lastly 5 (Strongly Disagree). There were 30 questions in total for a set of questionnaires. The questionnaire has two sections which are Section A and Section B. It began with the demographic profile of the respondents in Section A and continued with Section B which was their perceptions towards the activities carried out. In section B, the questions are divided into three sub-topics which were 1) Self-confidence, 2) Motivation and 3) Learning Environment. Each sub-topic contains 10 questions. Respondents answered the questionnaire individually.

\subsection{Data analysis}

The results were analysed by using Statistical Package for the Social Science (SPSS). In this study, SPSS was the best tool to get numerical data and clearer results for the questionnaire. By using SPSS different results that involve both demographic profile and respondents' perceptions could be shown. Hence, SPSS provided the best answer that explained the relation between the Interactive Language Learning Activities (ILLA) and learners' English language speaking engagement. The data was analysed according to the research questions. In this study, the findings were resulted to answer two research questions. Two tables were constructed according to two research questions with the percentage of questions according to Likert Scale and the mean. There were 16 questions depicted and were analysed from the overall 30 questions to answer the two research questions. The number of frequencies $=\mathrm{n}$ and percentage $=\%$ in the two tables explained the responses for the questionnaire.

\section{RESULTS}

To answer the first research question, the participants were required to share their perceptions towards self-confidence and learning environment through Interactive Language Learning Activities in improving English-speaking ability. Table 1 shows the results chosen by the participants. Table 1 shows different results of participants' perceptions towards self-confident and learning environment through interactive language learning activities in improving English-speaking ability which are represented by the highest percentage and mean for each category. As shown in the table, 'ILLA increases my confident to use English language with my friends' obtained the most agreement with a total of $82 \%$ and the mean score is 4.22. The second most agreed statement by the participants is 'ILLA encourages me to share my ideas during the learning activities' acquired $78 \%$ with the mean score of 4.0 . In addition, $80 \%$ of the participants agreed with the following statement 'ILLA enables me to use new vocabulary during the learning activities' by having 3.96 of the mean score.

Table 1. Percentage and mean results of research question 1 analysis

\begin{tabular}{|c|c|c|c|c|c|c|}
\hline \multirow[b]{2}{*}{ Question(s) } & \multicolumn{5}{|c|}{ Percentage $(\%)$} & \multirow[b]{2}{*}{ Mean } \\
\hline & $\begin{array}{l}\text { Strongly } \\
\text { Disagree }\end{array}$ & Disagree & Sometime & Agree & $\begin{array}{l}\text { Strongly } \\
\text { Agree }\end{array}$ & \\
\hline $\begin{array}{l}\text { 1. ILLA increases my confidence to use English language with my } \\
\text { friends }\end{array}$ & - & 2 & 16 & 40 & 42 & 4.22 \\
\hline $\begin{array}{l}\text { 2. ILLA encourages me to share my ideas during the learning } \\
\text { activities }\end{array}$ & 2 & - & 20 & 54 & 24 & 4.0 \\
\hline $\begin{array}{l}\text { 3. ILLA enables me to use new vocabulary during the learning } \\
\text { activities }\end{array}$ & - & 2 & 18 & 62 & 18 & 3.96 \\
\hline $\begin{array}{l}\text { 4. I do not enjoy speaking during ILLA because I am not confident } \\
\text { with my English language proficiency }\end{array}$ & 28 & 30 & 26 & 12 & 4 & 2.34 \\
\hline 5. ILLA provides a positive environment to speak English language & - & - & 14 & 56 & 30 & 4.16 \\
\hline 6. ILLA allows me to actively participate in the learning activities & 2 & 4 & 14 & 52 & 28 & 4.0 \\
\hline 7. I find it difficult to understand the instructions for the ILLA & 12 & 34 & 40 & 12 & 2 & 2.58 \\
\hline $\begin{array}{l}\text { 8. I fine ILLA is too distracting for me to improve me English } \\
\text { speaking }\end{array}$ & 18 & 50 & 18 & 12 & 2 & 2.30 \\
\hline $\begin{array}{l}\text { 9. ILLA supports my ability to engage with learning activities in } \\
\text { multiple ways (presentations, storytelling, group discussions, etc) }\end{array}$ & - & 18 & 16 & 48 & 28 & 3.96 \\
\hline
\end{tabular}


However, with the mean score of $2.34,58 \%$ of the participants disagreed that they do not enjoy speaking during ILLA because they do not feel confident with their English language proficiency. Continuously, the participants highly agreed on 'ILLA provides a positive environment to speak English language'. It can be seen by $86 \%$ of them agreed on the statement and accompanied with the mean score of 4.16. Furthermore, they agreed that ILLA allows them to actively participate in the learning activities. The stated statement acquired $80 \%$ agreement from the participants and the mean score is 4.0 . Moreover, $76 \%$ of the participants with the mean score of 3.96 agreed by the statement 'ILLA supports my ability to engage with learning activities in multiple ways (i.e presentations, storytelling, group discussions and etc). In contrast, $68 \%$ of the participants with 2.30 of the mean score disagreed that ILLA is too distracting for them to improve their English speaking. On the other hand, to answer the second research question, the participants are required to share their perceptions towards motivation Interactive Language Learning Activities in improving English-speaking ability. Table 2 shows results of participants' perceptions towards motivation through interactive language learning activities in improving English language communicatively which are represented by the highest percentage and mean for each category.

Table 2. Percentage and mean results of research question 2 analysis

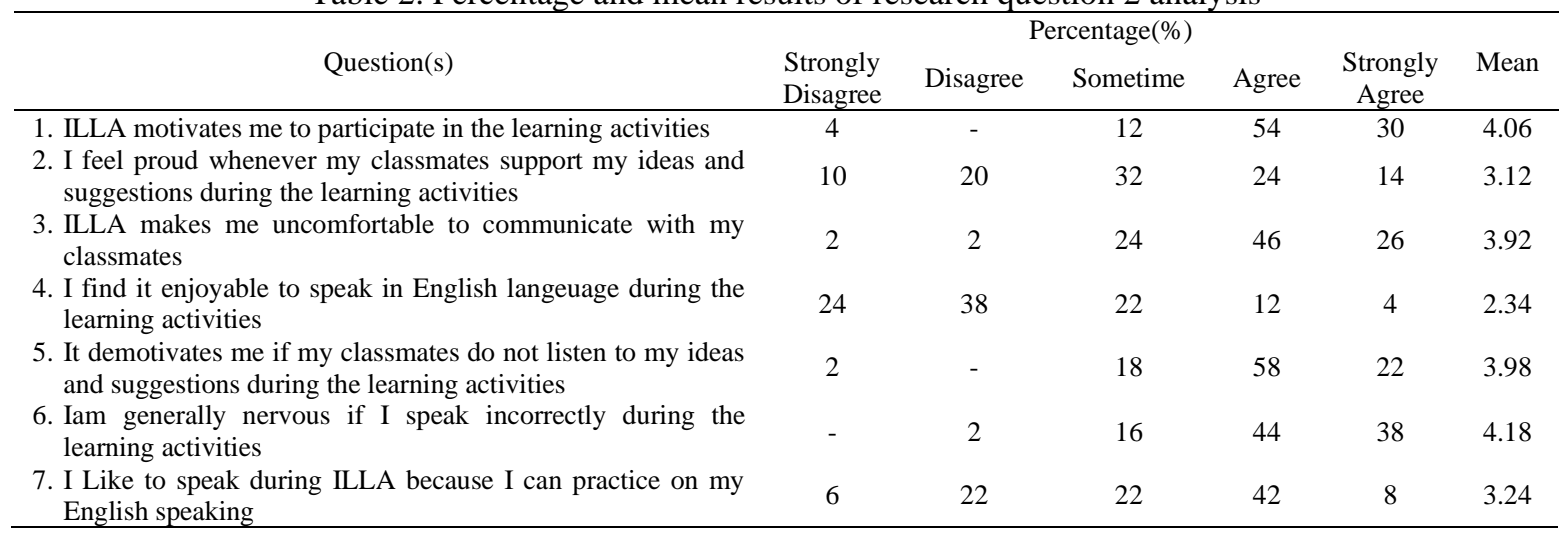

From the Table 2 above, the participants highly agreed on the statement 'ILLA motivates me to participate in the learning activities. It obtained $84 \%$ agreement by the participants with the mean score of 4 . 06 . Adding to that, $50 \%$ of the participants placed 'I like to speak during ILLA because I can practice on my English speaking' as the second most agreed statement with the mean score of 3.24. Moreover, with a mean score of 3.12 and $8 \%$ of the participants agreed that they feel proud whenever their classmates support their ideas and suggestions during the learning activities. On the contrary, the negative statement 'I am generally nervous if I speak incorrectly during the learning environment' obtained the highest mean which is 4.18 and the most number of agreement among the participants with $82 \%$. Besides, $80 \%$ of the participants and the mean score of 3.98 agreed that ILLA demotivates them if their classmates do not listen to their ideas and suggestions during the learning activities. Apart from that, $72 \%$ of the participants did not find it enjoyable to speak in English language during the learning activities. As can be seen in table, the mean scored this statement secured 2.34. Finally, 24\% of the participants were uncertain that ILLA makes them comfortable or not to communicate with their classmates by having 3.92 of the mean score.

\section{DISCUSSION}

In correlation with the study, perceptions towards interactive language learning activities in improving English speaking, and thus answering two specific research questions, quantitative method is applied. A test was conducted to analyse the percentage and the mean of the questionnaire answered by the participants. Based on the findings, there is a significant result that aid to the improvement of English speaking. In improving English speaking communicatively, there are three important items which are analysed accordingly including self-confidence, motivation and learning environment. As for answering the first research question, how does the interactive language learning activities aid learners in improving their English speaking, the participants came to an agreement for certain questions based on the questionnaire which was resulted in the findings. The answers were divided into two categories which are self-confidence and learning environment. Thus, the highest mean showed that interactive language learning activities increased their confident to use English language with their friends. It was because interactive language 
learning activities provide learners a positive environment to speak English language. This particular result reflected the previous study by Marzuki, Prayogo and Wahyudi [4], which stating that the learners' speaking performance improved as they are participating in interactive learning. The improvement derived from generating questions that initially to improve their self-confidence. They improved their self-confidence as they were required to formulate their own questions during the learning process.

Furthermore, the participants were highly agreed that interactive language learning activities encouraged them to share their ideas during the learning activities and enable them to use new vocabulary during the learning activities. Based on their perceptions, it could be said that by sharing ideas, they naturally enhance their vocabulary usage as they need to fit in with their classmates during the implementation of the activities. This finding is also in line with the study conducted by Marzuki, Prayogo and Wahyudi [4]. Consequently, having sufficient vocabulary during the activities helps the learners to actively participate in the learning activities. Learners were also seen to be able to engage with the learning activities in various ways which lead to the improvement of their English speaking. With the activities focus on learners' engagement with course content and learner-learner interactivity, hence, learning could be optimized [21]. In addition, the findings shown that the participants like and not reluctant to speak during the learning activities even though not all of them may have the confidence to speak due to the positive learning environment. They felt at ease and relax to speak during interactive language learning activities as they were not bounded to any rule that they needed to follow strictly [22]. One of the most valuable benefits of interactive tasks is the principle of collaboration which features the components of positive accountability [23]. Moreover, the participants agreed that interactive language learning activities is the best way to improve their English speaking. However, some of them felt that the instructions used during the activities were difficult to understand which can lead to ineffective lesson. The integration of technologies can then be viewed as a vehicle to improve learner outcomes [24].

In regard to the findings, interactive language learning activities motivate the learners to speak in English language. As interactive language learning activities provide positive surroundings to the learners, they felt motivated to participate in the learning activities and thus improved their English-speaking ability. Besides, getting recognition by the classmates during the learning activities had also motivated learners to speak. It was because they felt proud when their ideas and suggestions were accepted, and it was beneficial for them to participate in the learning activities. They continued to share their ideas and suggestions during the learning activities and improved their English communicatively. Furthermore, learners enjoyed speaking during the learning activities as it allowed them to practice speaking.

Some of the learners acquired different knowledge or information throughout the learning process. Their ability to understand things were different and interactive language learning activities provided the opportunities for the learners to put everything that they had learnt in written form to practice. Therefore, educators need to know and resolve the learners' issues and to make schools engaging places [25, 26], then they actually have to listen to what learners are saying about their classes and teachers [27-30]. By practicing, they could enhance their understanding towards the lesson learnt. On the other hand, the findings showed that interactive language learning activities could be demotivating if the learners' opinions were being neglected by their classmates. When the learners participated in the learning activities, they were hoping to assist their classmates in completing their tasks. However, if their ideas were rejected, they felt embarrassed and the probability for them not to speak during the discussion again was high which was not contributing to their English-speaking improvement. Study by Rusli, et al. [11] stated that learners were afraid of peers' judgement. It was said that learners were unlikely to speak as they wanted to avoid from showing their flaws where they could receive negative views from their classmates. Equally important, some of the learners had low motivation in speaking as they were afraid to speak incorrectly during the learning activities.

\section{CONCLUSION}

As a whole, interactive language learning activities improve learners' English-speaking ability. In correlation with the findings, participants agreed that by having self-confidence, suitable learning environment and motivation improved their English speaking communicatively. Moreover, these three factors improved through interactive language learning. Furthermore, it showed that interactive language learning activities provide the ways to improve English speaking as learners were able to experience real conversation when they were interacting with their classmates during the learning activities. However, some participants needed time to speak as they have had low self-confidence and it led to low motivation to speak English language. Teachers' support in conducting suitable interactive language learning activities during English lesson is proved to be important for improving learners' English-speaking ability. 


\section{ACKNOWLEDGEMENTS}

We would like to thank the Malaysian Ministry of Higher Education for funding this study under Fundamental Research Grant Scheme (FRGS Nos. FRGS/1/2019/SSI09/UNISEL/03/4). This work was supported by Universiti Selangor (UNISEL).

\section{REFERENCES}

[1] F. Dağ, E. Şumuer, and L. Durdu, "Pre-Service Teachers' Perceptions and Experiences: Courses Based on the Active Learning Model and Environment," Journal of Learning Spaces, vol. 8, no. 2, pp. 41-56, 2019.

[2] S. Pradono, et al., "A Method for Interactive Learning," CommIT, vol. 7, no. 2, pp. 46-48, 2013.

[3] J. Atiyah, et al., "Education on E-learning program versus Traditional Instruction for Undergraduate," International Journal of Advanced Research in Science, Engineering and Technology, vol. 2, no. 7, pp. 776-786, 2015.

[4] Marzuki, J. A. Prayogo, and A. Wahyudi, "Improving the EFL Learners' Speaking Ability through Interactive Storytelling," Dinamika Ilmu, vol. 16, no. 1, pp. 15-34. 2016.

[5] Juhana, "Psychological factors that hinder students from speaking in English class (A Case study in a senior high school in South Tangerang, Banten, Indonesia)," J. of Education and Practice, vol. 3, no. 12, pp. 100-110, 2012.

[6] R. David, S. M. Thang, and H. Azman, "Accommodating Low Proficiency ESL Students' language Learning Needs Through an Online Writing Support System," e-Bangi, vol. 10, no. 1, p. 118, 2015.

[7] R. S. Dewi, U. Kultsum and A. Armadi, "Using Communicative Games in Improving Students' Speaking Skills," English Language Teaching, vol. 10, no. 1, pp. 63-71, 2017.

[8] Gocer, Turkish special teaching methods, (2nd Edition). Ankara: Pegem Academy Publishing, 2017.

[9] T. Türkben, "The Effects of Interactive Teaching Strategies on Speaking Skills of Students Learning Turkish as a Second Language," Journal of Language and Linguistic Studies, vol. 15, no. 3, pp. 1011-1031, 2019.

[10] H. Akyol, Turkish teaching methods, (7th Edition). Ankara: Pegem Academy Publishing, 2014.

[11] R. Rusli, et al., "Low Speaking Proficiency Among the Malaysian Undergraduates: Why and How?" e-Prosiding Persidangan Antarabangsa Sains Sosial \& Kemanusiaan 2018 (PASAK3), pp. 678-689, 2018.

[12] G. Ari, "Speech training. M. Durmus and A. Okur (Eds.), In the Handbook of Teaching Turkish as a Foreign Language. Ankara: Grafiker Publishing, pp. 277-293, 2018.

[13] O. Demirel, Foreign language teaching, (9th Edition). Ankara: Pegem Academy Publishing, 2016.

[14] K. U. Isisag, and Ö. Demirel, "The use of the Common European Framework of Reference for Languages on developing the speaking skills," Education and Science, vol. 35, no. 156, pp. 190-204, 2010.

[15] G. Tum, "Phonological problems encountered in multinational classrooms in teaching Turkish as a foreign language," H. U. Journal of Education, vol. 29, no. 2, pp. 255-266, 2014.

[16] N. Aykac, Principles and methods of teaching. Ankara: Pegem Academy Publishing, 2016.

[17] Akhyak and A. Indramawan, "Improving the Students' English Speaking Competence through Storytelling: Study in Pangeran Diponegoro Islamic College (STAI) of Nganjuk, East Java, and Indonesia," International Journal of Language and Literature, vol. 1, no. 2, pp. 18-24, 2013.

[18] C. Gill, "Oral communication in ESL through Improvisations, Playwriting and Rehearsals," Advances in Language and Literacy Studies, vol. 4, no. 1, pp. 35-40, 2013.

[19] J. W. Creswell, Research Design: Qualitative, Quantitative and Mixed Methods Approaches, (4th ed.). Thousand Oaks, CA: Sage, 2014.

[20] G. Itayem, "Using the iPad in language learning: Perceptions of college students," Doctoral dissertation, The University of Toledo, Toledo, $\mathrm{OH}, 2014$.

[21] K. Swartwelder, J. Murphy, and G. Murphy, "The Impact of Text-Based and Video Discussions on Student Engagement and Interactivity in an Online Course," Journal of Educators Online, vol. 6, no. 1, pp. 1-7, 2019.

[22] K. Pong, "Learners' Anxieties on Posting Their Own Speeches on Youtube.com: Facilitative or Debilitative?" Colleğe English: Issues and Trends, vol. 3, pp. 73-100, 2010.

[23] M. A. Christison, and D. E. Murray, What English language teachers need to know, Vol. III: Designing curriculum. New York, NY: Routledge, 2014.

[24] B. Lawrence, and S. Lentle-Keenan, "Teaching beliefs and practice, institutional context, and the uptake of Webbased technology," Distance Education, vol. 34, no. 1, pp. 4-20, 2013.

[25] E. J. Meyer, "Transforming school cultures," in Gender and Sexual Diversity in Schools, Explorations of Educational Purpose. Springer Nature, pp. 121-139, 2010.

[26] J. Smyth, and P. McInerney, Teachers in the middle: Reclaiming the wasteland of the Adolescent years of schooling. New York, USA: Peter Lang, 2007.

[27] D. L. Mitra, and S. C. Serriere, "Student Voice in Elementary School Reform Examining Youth Development in Fifth Graders," American Educational Research Journal, vol. 49, no. 4, pp. 743-774, 2012.

[28] P. O'Brien, and M. Lai, "Student Voice: How can it help us to understand students' experiences of school?" Assessment Symposium, Rutherford House, Wellington, New Zealand, 2011.

[29] G. Potter, and F. Briggs, "Children talk about their early experiences at school," Australian Journal of Early Childhood, vol. 28, no. 3, pp. 44-49, 2003.

[30] D. Zyngier, "(Re)conceptualising risk: left numb and unengaged and lost in a no-man's-land or what (seems to) work for at-risk students," International Journal of Inclusive Education, vol. 15, no. 2, pp. 211-231, 2011. 